\title{
Chemical Composition, Antioxidant Potential, and Antibacterial Activity of Essential Oil Cones of Tunisian Cupressus sempervirens
}

\author{
Aicha Ben Nouri, ${ }^{1}$ Wissal Dhifi, ${ }^{2}$ Sana Bellili, ${ }^{1}$ Hanene Ghazghazi, ${ }^{3}$ Chedia Aouadhi, ${ }^{4}$ \\ Ameur Chérif, ${ }^{1}$ Mohamed Hammami, ${ }^{5,6}$ and Wissem Mnif ${ }^{1,7}$ \\ ${ }^{1}$ LR11-ES31 Biotechnologie et Valorisation des Bio-Géo Ressources, Institut Supérieur de Biotechnologie de Sidi Thabet, \\ Université de la Manouba, BiotechPole de Sidi Thabet, 2020 Sidi Thabet, Tunisia \\ ${ }^{2}$ UR Ecophysiologie Environnementale et Procédés Agroalimentaires, Université de la Manouba, BiotechPole de Sidi Thabet, \\ 2020 Sidi Thabet, Tunisia \\ ${ }^{3}$ Laboratory of Management and Valorization of Forest Resources, National Research Institute of Rural Engineering, \\ Water and Forestry (INRGREF), 1002 Tunis, Tunisia \\ ${ }^{4}$ Laboratoire d'Epidémiologie et Microbiologie Vétérinaire, Groupes de Bactériologie et Développement Biotechnologique, \\ Institut Pasteur de Tunis, Université El Manar, 1002 Tunis, Tunisia \\ ${ }^{5}$ USCR de Spectrométrie de Masse, Laboratoire de Biochimie, Faculté de Médecine, 5019 Monastir, Tunisia \\ ${ }^{6}$ Institut National de Recherche et d'Analyses Physicochimique (INRAP), Université de la Manouba, BiotechPole de Sidi Thabet, \\ 2020 Sidi Thabet, Tunisia \\ ${ }^{7}$ Faculty of Sciences and Arts in Balgarn, Bisha University, P.O. Box 60, Balgarn, Sabt Al Alaya 61985, Saudi Arabia
}

Correspondence should be addressed to Wissem Mnif; w_mnif@yahoo.fr

Received 8 May 2015; Revised 4 July 2015; Accepted 7 July 2015

Academic Editor: Patricia Valentao

Copyright (C) 2015 Aicha Ben Nouri et al. This is an open access article distributed under the Creative Commons Attribution License, which permits unrestricted use, distribution, and reproduction in any medium, provided the original work is properly cited.

\begin{abstract}
The extraction yield of the essential oil (EO) extracted by hydrodistillation from the cones of Tunisian Cupressus sempervirens L. was of $0.518 \%$. The chemical composition was analyzed by GC-MS. Results showed that this essential oil was mainly composed of monoterpene hydrocarbons $(65 \%)$ with $\alpha$-pinene as the major constituent $(47.51 \%)$. Its antioxidant activity was ascertained by evaluating the total antioxidant capacity and also by evaluating its inhibitory effect against DPPH and ABTS radicals. In addition, it showed a strong antioxidant power against the DPPH $\left(\mathrm{IC}_{50}=151 \mu \mathrm{g} / \mathrm{mL}\right)$ and $\mathrm{ABTS}\left(\mathrm{IC}_{50}=176.454 \mu \mathrm{g} / \mathrm{mL}\right)$ radicals scavenging. Moreover, its antibacterial activity was tested against different species of pathogenic bacteria (three Gram-positive and eight Gramnegative bacteria). The bacterial strains susceptible to the evaluated oil were Bacillus subtilis, Escherichia coli, Klebsiella oxytoca, Morganella morganii, Shigella, and Vibrio cholerae.
\end{abstract}

\section{Introduction}

Cupressus (Cupressaceae), comprising twelve species, is distributed in North America, the Mediterranean region, and subtropical Asia at high altitudes [1]. The geographic area of Cupressus genus is limited to the northern hemisphere and many species have been studied $[2,3]$. In Tunisia, only one species of the genus Cupressus, Cupressus sempervirens L. [4], was native.
Cupressus sempervirens L. is a medicinal plant. The dried leaves of this plant are used as an emmenagogue and for stomach pain [5] as well as for diabetes [6]. Its dried fruit plant is used for inflammation treatment [7], toothache, and laryngitis [8] and also as a contraceptive [9], astringent, and antiphrastic drug [10]. The dried seed of this tree has been used for wounds, ulcers, bruises, sores, pimples, pustules, skin eruptions, and erysipelas [11]. Cupressus sempervirens essential oil 
is used externally for headache, colds, cough, and bronchitis [12].

Studies on phytochemical compounds of Cupressus sempervirens $\mathrm{L}$. revealed that it contains active constituents such as flavonoids (cupressuflavone, amentoflavone, rutin, quercitrin, quercetin, and myricitrin), phenolic compounds (anthocyanidin, catechins flavones, flavonols and isoflavones, tannins, and catechol), and essential oils (EO) $[13,14]$. It has been demonstrated that principals active from Cupressus sempervirens L. display antiseptic, aromatherapeutic, astringent, balsamic, and anti-inflammatory activities [15]. Cupressus sempervirens L. antimicrobial activity has been reported in several studies $[14,16]$.

Even studies have focused on chemistry and biological activities of Cupressus sempervirens L. leaves originating from different areas in the world [14, 16, 17]; there is no report concerning this species (cones) in Tunisia. The aim of this study is to ascertain the chemical composition of the EO of Tunisian Cupressus sempervirens L. cones and to evaluate its antioxidant and antibacterial activities.

\section{Materials and Methods}

2.1. Plant Material. Cones (the aerial parts) of Cupressus sempervirens L. were collected from Sidi Thabet (North of Tunisia) in March 2014. The botanical identification was achieved by Pr. Mohammed Chaeib from the Faculty of Sciences of Sfax-Tunisia. Female cones were dried at room temperature for 7 days and used for analyses. Voucher specimens of the plants were deposited in the Herbarium of this laboratory.

\subsection{Extraction of the Essential Oil. Cupressus sempervirens} cones were dried at room temperature. After that, $100 \mathrm{~g}$ of dry matter was used for essential oil extraction by hydrodistillation in a Clevenger apparatus for four hours. The resulting essential oil recovered is dried by anhydrous sodium sulphate and then stored at $4^{\circ} \mathrm{C}$ for further analysis.

2.3. Analysis of the Essential Oil. Cupressus sempervirens L. essential oil composition was investigated by GC and GC/MS. The analytical GC was carried out on an HP5890-series II gas chromatograph (Agilent Technologies, California, USA) equipped with Flame Ionization Detectors (FID) under the following conditions: the fused silica capillary column, apolar HP-5, and polar HP Innowax ( $30 \mathrm{~m} \times 0.25 \mathrm{~mm}$ ID, film thickness of $0.25 \mathrm{~mm}$ ). The oven temperature was held at $50^{\circ} \mathrm{C}$ for $1 \mathrm{~min}$, then programmed at rate of $5^{\circ} \mathrm{C} / \mathrm{min}$ to $240^{\circ} \mathrm{C}$, and held isothermal for $4 \mathrm{~min}$. The carrier gas was nitrogen at a flow rate of $1.2 \mathrm{~mL} / \mathrm{min}$; injector temperature: $250^{\circ} \mathrm{C}$; detector: $280^{\circ} \mathrm{C}$; the volume injected: $0.1 \mathrm{~mL}$ of $1 \%$ solution (diluted in hexane). The percentages of the constituents were calculated by electronic integration of FID peak areas without the use of response factor correction. GC/MS was performed in a Hewlett-Packard 5972 MSD System. An HP-5 MS capillary column $(30 \mathrm{~m} \times 0.25 \mathrm{~mm}$ ID, film thickness of $0.25 \mathrm{~mm})$ was directly coupled to the mass spectrometry. The carrier gas was helium, with a flow rate of $1.2 \mathrm{~mL} / \mathrm{min}$. Oven temperature was programmed $\left(50^{\circ} \mathrm{C}\right.$ for $1 \mathrm{~min}$, then $50-240^{\circ} \mathrm{C}$ at $\left.5^{\circ} \mathrm{C} / \mathrm{min}\right)$ and subsequently held isothermal for $4 \mathrm{~min}$; injector port: $250^{\circ} \mathrm{C}$; detector: $280^{\circ} \mathrm{C}$; split ratio: $1: 50$; volume injected: $0.1 \mathrm{~mL}$ of $1 \%$ solution (diluted in hexane); mass spectrometer: HP5972 recording at $70 \mathrm{ev}$ scan time: $1.5 \mathrm{~s}$; mass range: $40-300 \mathrm{amu}$. Software adopted to handle mass spectra and chromatograms was ChemStation. The identification of the compounds was based on mass spectra (compared with Wiley 275.L, 6th edition mass spectral library). Further confirmation was done from Retention Index data generated from a series of alkanes retention indices (relative to $\mathrm{C} 9-\mathrm{C} 28$ on the HP-5 and HP20M columns) [18].

\subsection{Antioxidant Activities}

2.4.1. Evaluation of Total Antioxidant Capacity. The total antioxidant capacity is based on the reduction of Mo (VI) to Mo (V) by the oil and the formation of a phosphate subsequent green/Mo (V) complex at acid $\mathrm{pH}$ [19]. In a reaction volume of $1 \mathrm{~mL}$ was added to different concentrations of tested oil and standard sulfuric acid $(0.6 \mathrm{M})$, sodium phosphate $(28 \mathrm{mM})$, and ammonium molybdate $(4 \mathrm{mM})$. The solutions were then incubated in a water bath at $95^{\circ} \mathrm{C}$ for 1 hour. After cooling to room temperature, the optical density is measured at $695 \mathrm{~nm}$. Each fraction was analyzed in triplicate.

2.4.2. DPPH Radical-Scavenging Activity. The ability of our essential oil to reduce the DPPH was measured according to the method described by Tuberoso [20]. For each concentration, one milliliter was added to $0.25 \mathrm{~mL}$ of ethanolic solution of DPPH. The mixture was stirred vigorously and then incubated at room temperature for $30 \mathrm{~min}$ in the dark. The absorbance illustrating the power of the extract to reduce the free radical DPPH to the yellow-colored diphenylpicrylhydrazine was measured at $520 \mathrm{~nm}$. So, antiradical activity is expressed as $\mathrm{IC}_{50}\left(\mu \mathrm{g} \mathrm{mL}^{-1}\right)$, the extract dose required to induce a $50 \%$ inhibition. The ability to scavenge the DPPH radical was calculated using the following equation: DPPH scavenging effect $=\left[\left(A_{0}-A_{1}\right) / A_{0}\right] \times 100$, where $A_{0}$ and $A_{1}$ were the absorbance of the control and the sample after $30 \mathrm{~min}$, respectively. Each experiment was analyzed in triplicate.

2.4.3. ABTS Assay. For ABTS assay, we used the method described by Hayouni et al. [21]. The stock solutions included $7 \mathrm{mM} \mathrm{ABTS}^{\circ+}$ and $2.45 \mathrm{mM}$ potassium persulfate solution. The working solution was then prepared by mixing the two stock solutions in equal quantities and allowing them to react for $12 \mathrm{~h}$ at room temperature in the dark. The solution was then diluted by mixing $1 \mathrm{~mL} \mathrm{ABTS}{ }^{*+}$ solution with $50 \mathrm{~mL}$ methanol to obtain an absorbance of $0.7 \pm 0.02$ units at $734 \mathrm{~nm}$ using the spectrophotometer 6305 UV-VIS. Fresh $\mathrm{ABTS}^{\circ+}$ solution was prepared for each assay. $50 \mu \mathrm{L}$ of each concentration of the essential oil is added with $950 \mu \mathrm{L}$ of $\mathrm{ABTS}^{\circ+}$ solution, allowed to react in the dark and then we follow the kinetics of this mixture every $5 \mathrm{~min}$ for $30 \mathrm{~min}$. Then the absorbance was measured at $734 \mathrm{~nm}$. Antiradical activity is expressed as $\mathrm{IC}_{50}\left(\mu \mathrm{g} \mathrm{mL}^{-1}\right)$, the extract dose required to induce a $50 \%$ inhibition. A low $\mathrm{IC}_{50}$ value corresponds to 
a high antioxidant activity of plant extract. Results are expressed in $\mu \mathrm{g}$ Trolox equivalents (TE)/mg dry mass. The percentage inhibition of the ABTS cation radical by the samples was calculated according to the following formula: Inhibition percentage $(\%$ inhibition $)=\left(A_{0}-A_{t}\right) /\left(A_{0} \times 100\right)$, where $A_{0}$ is absorbance of control sample $(t=0 \mathrm{~h})$ and $A_{t}$ is absorbance of a tested sample in 5 or $30 \mathrm{~min}$.

\subsection{Antimicrobial Activities}

2.5.1. Microorganisms. The tested microorganisms include Gram-positive bacteria, Staphylococcus aureus ATCC 29213, Bacillus subtilis ATCC 6633, and Bacillus cereus ATCC 11778, and Gram-negative bacteria: Escherichia coli ATCC 8739, Klebsiella oxytoca CECT 8207, Salmonella salamae ATCC 43972, Salmonella typhi ATCC 25241, Morganella morganii ATCC 25830, Salmonella anatum ATCC 9270, Vibrio cholerae CECT 8265, and Shigella ATCC 29930.

2.5.2. Disk-Diffusion Assay. Antibacterial activity was evaluated using the method described by Choi et al. (2006) [22]. The principle of this method is to use Whatman paper discs of $6 \mathrm{~mm}$ in diameter. The discs were impregnated with essential oil diluted in hexane. A disc soaked in hexane was used as negative control. These discs are then deposited on the surface of a middle swab with a bacterial suspension to an optical density of $0.5 \mathrm{McF}$ arlend standard. We used the bacterial strains for the culture medium Muller-Hinton. At the end of the incubation, 24 hours at $37^{\circ} \mathrm{C}$, the diameters of the zone of inhibition were measured.

2.5.3. Minimum Inhibitory Concentration. A broth microdilution was used to determine the minimum inhibitory concentration (MIC). The tests were performed in MullerHinton Broth. The essential oil was dissolved in Tween 80. A serial doubling of tested oil was prepared in a 96-well microtiter plate over the range $78 \mu \mathrm{g} / \mathrm{mL}-1 \mathrm{mg} / \mathrm{mL}$. In each well containing a concentration was added $100 \mu \mathrm{L}$ of bacterial suspension of 106 (0.5 MacFarlen standard). We incubated plates overnight at $37^{\circ} \mathrm{C}$ and then measured the optical density at $620 \mathrm{~nm}$.

\section{Results and Discussion}

3.1. Chemical Composition. The extraction yield of the EO from the cones of Tunisian Cupressus sempervirens L. was of $0.518 \%$. The coupling analysis of GC/MS and GC-FID/KI revealed 67 compounds (Figure 1). The major compound was $\alpha$-pinene $(47.51 \%)$. It was followed by $\delta$-3-carene, $\alpha$-terpinyl acetate, $\beta$-caryophyllene, and $\alpha$-cedrol whose proportions were $7.40,4.11,4.53$, and $4.99 \%$, respectively (Table 1 ). These results are in accordance with those reported by Boukhris et al. (2012) [17] for Cupressus sempervirens L. collected from the random gardens in Sfax, Tunisia, and characterized by $\alpha$-pinene (37.14\%), $\delta$-3-carene (19.67\%), limonene $(5.43 \%)$, and $\alpha$-terpinolene $(4.69 \%)$ as the most abundant volatiles. Furthermore, Riahi et al. (2012) [23] reported a yield of $0.92 \%$ for Tunisian Cupressus sempervirens L. It is higher than

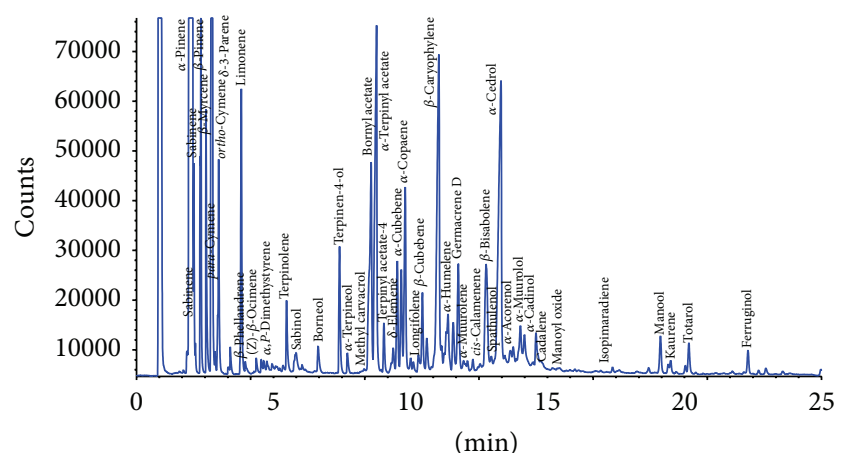

Figure 1: Essential oil chromatogram from cones of Cupressus sempervirens.

that obtained for Algerian C. sempervirens (0.26\%) [14] and comparable to that of the Cameroon species (1\%) [24].

The major components of Tunisian Cupressus sempervirens L. as reported by Riahi et al. (2012) [23] were $\alpha$-terpinolene $(24.44 \%), 3$-carene (18.60\%), $\alpha$-limonene (11.61\%), terpinen-4-ol (10.56\%), $\beta$-myrcene $(4.89 \%)$, camphor $(4.62 \%)$, and $\beta$-linalool (4.23\%). For essential oils of most Cupressus species, $\alpha$-pinene and 3 -carene were cited as the major compounds [25]. However in our sample $\alpha$-pinene component is absent. Results by Tapondjou et al. (2005) revealed that the oil from Cupressus sempervirens L. in Cameroon mainly consists of $\alpha$-pinene $(9.9 \%)$, terpinen-4-ol $(11.2 \%)$, and sabinene (14.8\%).

Moreover, $\alpha$-pinene and $\gamma$-terpinene accounted, respectively, for 39.5 and $11.56 \%$ of the whole essential oil of Cupressus sempervirens L. cones originating from Greece [26]. The cone essential oil of Egyptian Cupressus sempervirens L. showed antibacterial activity [27]. It is in contradiction with the results reported by Chéraif et al. (2005) [28]. Indeed, $\alpha$ pinene is present in the essential oil of Cupressus sempervirens L. leaves at a low rate $(20 \%)$ compared with that of cone essential oil. In addition, the proportion of $\delta$-3-carene is important $(22.9 \%)$ in the essential oil branches of Cupressus sempervirens L. by comparison with that of cones (7.40\%). Limonene is of the order of $5.1 \%$ in the essential oils branches of Cupressus sempervirens L. Its rate is lower in cones essential oil (1.75\%). The same results have been reported for $\alpha$-terpinyl acetate whose rates were of $7.5 \%$ and $4.11 \%$, respectively, in branches and cones. Furthermore, $\beta$-caryophllene was detected as trace in twigs whereas its rate was of $4.53 \%$ in cones. Among volatiles, $\alpha$-terpinolene was present in the branches essential oil with an amount of $9.4 \%$. However, it was absent in cones essential oil.

Loukis et al. (1991) [26] reported that $\alpha$-pinene and $\gamma$ terpinene accounted, respectively, for 39.5 and $11.56 \%$ of the whole essential oil of Cupressus sempervirens L. cones originating from Greece.

Emami et al. (2004) [29] detected 42 compounds in the essential oil of cones Cupressus sempervirens L. originating from Egypt. They reported a yield of $0.26 \%$ for leaves essential oil. Tognolini et al. (2006) [30] reported that the $\alpha$-pinene is the major compound. This is the second monoterpene hydrocarbon predominant compound according to the results of 
TABLE 1: Essential oil composition from cones of Cupressus sempervirens.

\begin{tabular}{|c|c|c|c|c|c|}
\hline Number & Volatile compound & $\mathrm{RI}^{\mathrm{a}}$ & $\mathrm{RI}^{\mathrm{b}}$ & Amount (\% of whole EO) & Methods of identification \\
\hline 1 & Tricyclene & 924 & 1015 & 0.14 & MS, RI \\
\hline 2 & $\alpha$-Pinene & 939 & 1032 & 47.51 & MS, RI, Co-GLC \\
\hline 3 & $\alpha$-Fenchene & 953 & 1044 & 0.74 & MS, RI \\
\hline 4 & Camphene & 954 & 1076 & 0.15 & MS, RI, Co-GLC \\
\hline 5 & Sabinene & 976 & 1132 & 0.6 & MS, RI, Co-GLC \\
\hline 6 & $\beta$-Pinene & 980 & 1118 & 1.53 & MS, RI, Co-GLC \\
\hline 7 & $\beta$-Myrcene & 994 & 1174 & 1.28 & MS, RI, Co-GLC \\
\hline 8 & $\delta$-3-Carene & 1011 & 1159 & 7.4 & MS, RI, Co-GLC \\
\hline 9 & $\alpha$-Terpinene & 1018 & 1188 & 0.11 & MS, RI, Co-GLC \\
\hline 10 & p-Cymene & 1026 & 1280 & 0.2 & MS, RI, Co-GLC \\
\hline 11 & m-Cymene & 1023 & 1278 & 1.12 & MS, RI, Co-GLC \\
\hline 12 & Limonene & 1030 & 1203 & 1.75 & MS, RI, Co-GLC \\
\hline 13 & $\beta$-Phellandrene & 1006 & 1176 & 0.13 & MS, RI \\
\hline 14 & (Z)-b-Ocimene & 1040 & 1246 & 0.14 & MS, RI \\
\hline 15 & (E)-b-Ocimene & 1050 & 1266 & 0.12 & MS, RI \\
\hline 16 & g-Terpinene & 1062 & 1266 & 0.12 & MS, RI, Co-GLC \\
\hline 17 & $\alpha, \mathrm{p}$-Dimethylstyrene & 1080 & 1452 & 0.15 & MS, RI \\
\hline 18 & Fenchone & 1087 & 1406 & 0.13 & MS, RI \\
\hline 19 & Terpinolene & 1088 & 1290 & 0.6 & MS, RI, Co-GLC \\
\hline 20 & Sabinol & 1210 & 1800 & 0.24 & MS, RI \\
\hline 21 & Borneol & 1165 & 1719 & 0.31 & MS, RI \\
\hline 22 & Terpinen-4-ol & 1018 & 1188 & 0.97 & MS, RI, Co-GLC \\
\hline 23 & $\alpha$-Terpineol & 1189 & 1706 & 0.17 & MS, RI, Co-GLC \\
\hline 24 & Carvacrol, methyl ether & 1244 & 1586 & 0.07 & MS, RI, Co-GLC \\
\hline 25 & Bornyl acetate & 1295 & 1597 & 2.75 & MS, RI \\
\hline 26 & $\alpha$-Terpinyl acetate & 1350 & 1677 & 4.11 & MS, RI \\
\hline 27 & Terpinyl- 4 acetate & 1333 & 1709 & 0.39 & MS, RI \\
\hline 28 & $\delta$-Elemene & 1337 & 1479 & 0.24 & MS, RI \\
\hline 29 & $\alpha$-Cubebene & 1352 & 1468 & 0.93 & MS, RI \\
\hline 30 & $\alpha$-Ylangene & 1372 & 1493 & 0.9 & MS, RI \\
\hline 31 & $\alpha$-Copaene & 1376 & 1497 & 1.72 & MS, RI, Co-GLC \\
\hline 32 & $\beta$-Bourbonene & 1385 & 1535 & 0.15 & MS, RI \\
\hline 33 & $\beta$-Elemene & 1391 & 1600 & 0.12 & MS, RI \\
\hline 34 & Longifolene & 1413 & 1575 & 0.2 & MS, RI \\
\hline 35 & $\beta$-Cubebene & 1348 & 1456 & 0.69 & MS, RI \\
\hline 36 & $\alpha$-Gurjunene & 1408 & 1529 & 0.37 & MS, RI \\
\hline 37 & $\beta$-Caryophyllene & 1415 & 1612 & 4.53 & MS, RI \\
\hline 38 & $\beta$-Gurjunene & 1432 & 1612 & 0.2 & MS, RI \\
\hline 39 & $\alpha$-Cedrene & 1411 & 1568 & 0.14 & MS, RI \\
\hline 40 & Aromadendrene & 1439 & 1628 & 0.29 & MS, RI \\
\hline 41 & $\alpha$-Humulene & 1454 & 1687 & 0.64 & MS, RI, Co-GLC \\
\hline 42 & Alloaromadendrene & 1474 & 1661 & 0.54 & MS, RI \\
\hline 43 & Germacrene D & 1480 & 1696 & 1.14 & MS, RI, Co-GLC \\
\hline 44 & $\alpha$-Muurolene & 1477 & 1704 & 0.15 & MS, RI \\
\hline 45 & $\delta$-Cadinene & 1517 & 1773 & 0.11 & MS, RI \\
\hline 46 & cis-Calamenene & 1543 & 1837 & 0.16 & MS, RI \\
\hline 47 & Cadina-1,4-diene & 1552 & 1768 & 0.12 & MS, RI \\
\hline 48 & $\beta$-Bisabolene & 1508 & 1740 & 1.73 & MS, RI \\
\hline 49 & Spathulenol & 1576 & 2144 & 0.21 & MS, RI \\
\hline 50 & $\alpha$-Cedrol & 1597 & 2021 & 4.99 & MS, RI, Co-GLC \\
\hline
\end{tabular}


TABle 1: Continued.

\begin{tabular}{|c|c|c|c|c|c|}
\hline Number & Volatile compound & $\mathrm{RI}^{\mathrm{a}}$ & $\mathrm{RI}^{\mathrm{b}}$ & Amount (\% of whole EO) & Methods of identification \\
\hline 51 & T-Cadinol & 1642 & 2187 & 0.25 & MS, RI \\
\hline 52 & $\alpha$-Acorenol & 1630 & 2163 & 0.34 & MS, RI \\
\hline 53 & $\beta$-Acorenol & 1637 & 2212 & 0.31 & MS, RI \\
\hline 54 & epi- $\alpha$-Cadinol & 1640 & 2170 & 0.11 & MS, RI \\
\hline 55 & $\alpha$-Muurolol & 1642 & 2209 & 0.73 & MS, RI \\
\hline 56 & $\beta$-Eudesmol & 1650 & 2257 & 0.68 & MS, RI \\
\hline 57 & $\alpha$-Eudesmol & 1641 & 2216 & 0.17 & MS, RI \\
\hline 58 & $\alpha$-Cadinol & 1649 & 2255 & 0.55 & MS, RI \\
\hline 59 & Cadalene & 1674 & 2200 & 0.09 & MS, RI \\
\hline 60 & Sandaracopimara-8(14),15-diene & 1960 & 2255 & 0.04 & MS, RI \\
\hline 61 & Manoyl oxide & 2010 & 2396 & 0.07 & MS, RI \\
\hline 62 & Isopimara-9-(11),15-diene & 1906 & 2175 & 0.05 & MS, RI \\
\hline 63 & Abietadiene & 2054 & 2530 & 0.05 & MS, RI \\
\hline 64 & Manool & 1989 & 2376 & 0.38 & MS, RI \\
\hline 65 & Kaurene & 2048 & 2399 & 0.13 & MS, RI \\
\hline 66 & Totarol & 2280 & 2314 & 0.31 & MS, RI \\
\hline \multirow[t]{2}{*}{67} & Ferruginol & 2295 & 2330 & 0.23 & MS, RI \\
\hline & & & & Total (\%) 97.69 & \\
\hline
\end{tabular}

RI: Retention Index; MS: mass spectrometry; Co-GLC: coinjection. $\%$ : percentage calculated by GC-FID on nonpolar HP-5 capillary column.

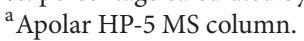

${ }^{\mathrm{b}}$ Polar HP Innowax column.

Sacchetti et al. (2005) [31]. Furthermore, the most abundant volatile compounds in the essential oil of Turkish Cupressus sempervirens L. are $\alpha$-pinene and $\Delta$-3-carene. Obviously, the composition of essential oils is significantly influenced by the organ. It is also influenced by many other factors including environmental factors such as rainfall, sunlight, soil, and climatic conditions and agronomic factors such as the date of harvest and the density of the culture.

3.2. Antioxidant Activities. Considering the many aspects of antioxidants and their reactivity, several tests are applied as antioxidants. Among them, the total antioxidant capacity, $\mathrm{DPPH}$, and ABTS radicals scavenging tests are used to determine the antioxidant power of essential oil.

The chemical complexity of essential oils, often a mixture of dozens of compounds with different functional groups, polarity, and antioxidant activity, may lead to scattered results, depending on the test employed [31].

3.2.1. Total Antioxidant Capacity. The total antioxidant activity of Cupressus sempervirens $\mathrm{L}$. is expressed as Trolox equivalent. The phosphomolybdenum method is based on the reduction of Mo (VI) with Mo (V) by the antioxidant compounds and the formation of a green phosphate/Mo complex (V). Our results showed that the antioxidant activity is proportional to the extract concentration $(0.0434 \mu \mathrm{g} \mathrm{ET} / \mathrm{g} \mathrm{DW})$ (Figure 2). Baykan Erel et al. (2012) [32] studied the antioxidant activity of essential oils of six species of Artemisia. It was noted that only essential oil of Artemisia absinthium and Artemisia arborescens has a total antioxidant activity with

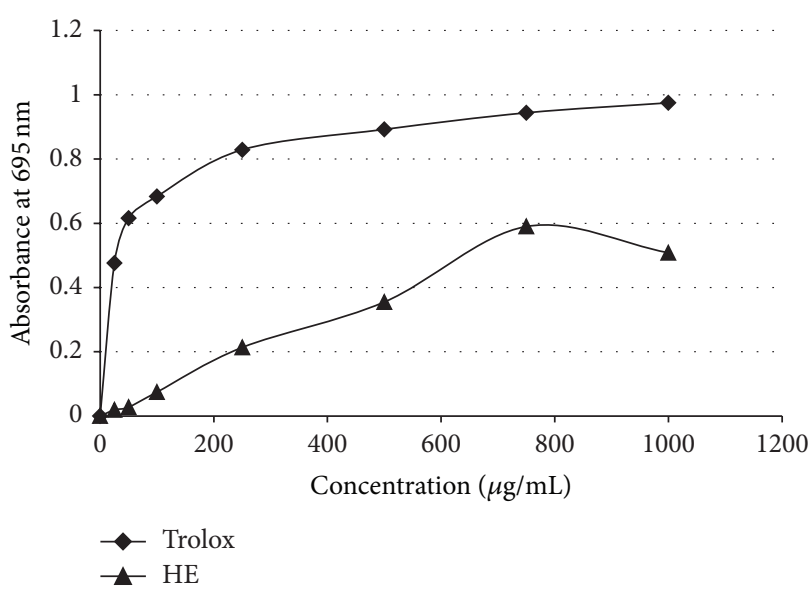

FIgure 2: Total antioxidant capacity from cones essential oil of Cupressus sempervirens.

values, respectively, in the order of $2.89 \mathrm{mgET} / \mathrm{g} \mathrm{DW}$ and $3.39 \mathrm{mg}$ ET/g DW.

3.2.2. DPPH Radical-Scavenging Activity. Free radical-scavenging activities of the tested oil and positive control (Trolox) are presented in Figure 3. In fact, Cupressus sempervirens L. essential oil remarkably reduced the concentration of DPPH free radical and transformed its stable, purple color into the yellow-colored DPPH-H with an efficiency IC $\mathrm{IC}_{50}=151 \mu \mathrm{g} / \mathrm{mL}$. The effect of antioxidant on DPPH radical scavenging was thought to be due to its hydrogen-donating ability. DPPH 
TABLE 2: Antibacterial activity from essential oil cones of Cupressus sempervirens.

\begin{tabular}{lcccccccccc}
\hline \multirow{2}{*}{ Microorganisms } & \multicolumn{1}{c}{ Concentration $(\mathrm{mg} / \mathrm{mL})$} & \multicolumn{3}{c}{ Negative control } \\
\hline Bacillus subtilis ATCC 6633 & 1 & 0.5 & 0.25 & 0.125 & 0.0625 & 0.0312 & 0.0156 & 0.0078 & + \\
Escherichia coli ATCC 8739 & - & - & - & + & + & + & + & + & + \\
Klebsiella oxytoca CECT 8207 & - & - & - & - & + & + & + & + \\
Morganella morganii ATCC 25830 & - & - & - & + & + & + & + & + & + \\
Shigella ATCC 29930 & - & - & - & - & + & + & + & + \\
Vibrio cholerae CECT 8265 & - & - & - & - & - & + & + & + & + \\
\hline
\end{tabular}

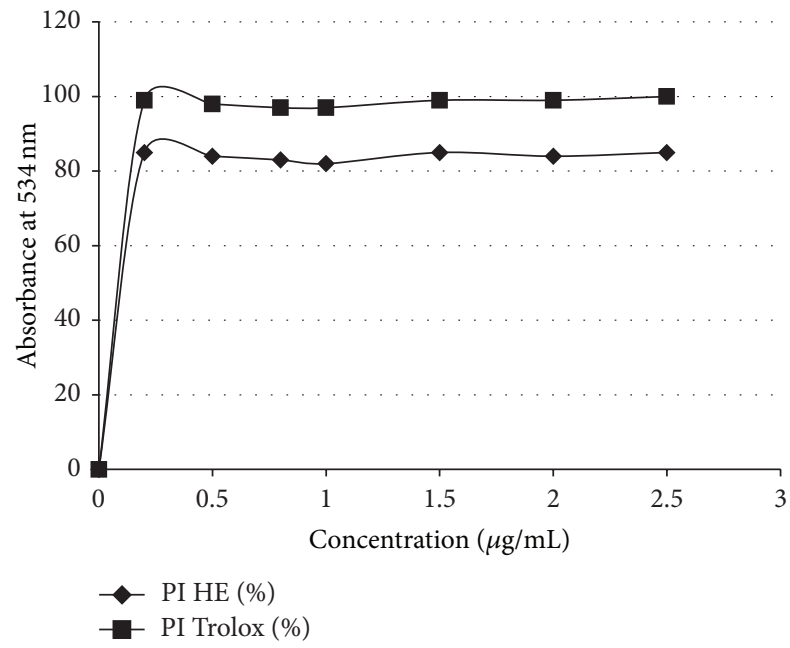

FIGURE 3: Scavenging of DPPH radical from cones essential oil of Cupressus sempervirens.

radical is a stable free radical and accepts an electron or hydrogen radical to become a stable diamagnetic molecule [33].

In two antioxidants screening studies Cupressus sempervirens $\mathrm{L}$. was reported to display moderate radical-scavenging effect against DPPH $[31,34]$. The leaf methanolic extract of Egyptian Cupressus sempervirens L. had strong DPPH radical-scavenging activity as reported by Ibrahim et al. (2009) [35].

Needless to say, potency of antioxidant activity of a substance is correlated with the applied method. In a study on some Iranian conifers the leaf and fruit $\mathrm{MeOH}$ extracts of Cupressus sempervirens L. were highly effective in ferric thiocyanate (FTC) and thiobarbituric acid (TBA) methods [36]. Nevertheless, activity of these extracts was also changeable according to the method.

3.2.3. ABTS Assay. Essential oil of Cupressus sempervirens L. had an antioxidant according to the DPPH test. The results relative to ABTS radical cation scavenging confirmed the previous result. In fact, $\mathrm{IC}_{50}$ obtained at the end of this test is $176.454 \mu \mathrm{g} / \mathrm{mL}$ (Figure 4). Ghazghazi et al. (2010) [37] obtained, by studying the essential oil samples of $R$. canina of Feija and Ain Draham (North of Tunisia) during the test of the ABTS, $\mathrm{IC}_{50}$ values of $159.0 \mu \mathrm{g} / \mathrm{mL}$ and $201.8 \mu \mathrm{g} / \mathrm{mL}$, respectively. From these results we can conclude

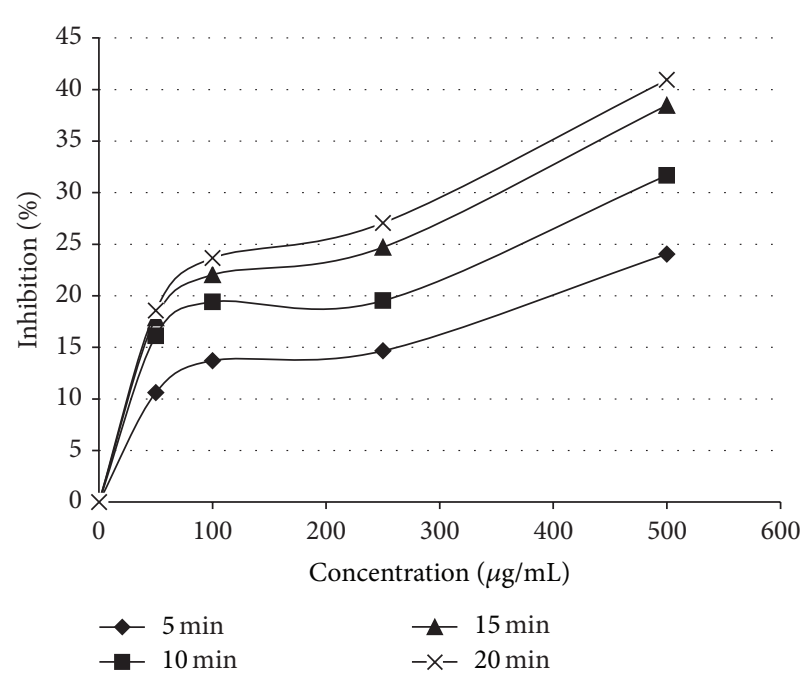

FIgURE 4: Scavenging of ABTS radical from cones essential oil of Cupressus sempervirens.

that the essential oil of Cupressus sempervirens L. has a strong antioxidant against ABTS cation. The antioxidant activity of essential oil could be assigned to the synergistic effects of two or more of its components. In this context, Lu and Foo (2001) [38] reported that most natural antioxidant compounds often work synergistically to produce a broad spectrum of antioxidant properties that create an effective defense system against free radicals. Cupressus sempervirens L. essential oil consists of a very complex mixture of various chemical classes (Table 1), which may produce either synergistic or antagonistic effects on the process of lipid oxidation [39].

3.3. Antibacterial Activity. The antibacterial test allowed us to determine the sensitive strains to the essential oil of Cupressus sempervirens $\mathrm{L}$. The screening of this activity was firstly determined by the disk-diffusion method on agar for predicting the inhibitory activity of the oil on the growth of a bacterial culture. Our results showed that the evaluated oil had significant antibacterial effect. In fact, among twelve tested strains, six were sensitive to this oil (Table 2). Gram-negative bacteria (Klebsiella oxytoca, Vibrio cholerae, Shigella, and E. coli) were the most sensitive strains with the MIC values that do not exceed $125 \mu \mathrm{g} / \mathrm{mL}$ of essential oil (Table 2). This finding was in agreement with other findings. For example, the cone EO of Egyptian Cupressus sempervirens L. showed 
antibacterial activity [27]. Chéraif et al. (2005) [28] tested the antibacterial activity of essential oil Cupressus sempervirens L. on Gram-positive and Gram-negative bacteria and found that this essential oil has a moderate activity against tested bacteria. It is important to mention that the activity was more pronounced for Gram-positive than Gram-negative bacteria. Similarly, Mazari et al. (2010) [14], when studying the biological activities of essential oils of Cupressus sempervirens L. and Juniperus phoenicea, reported that both oils constitute sources of antimicrobial agents. There are often large variations in the intensity of the antimicrobial activities against Gramnegative and Gram-positive bacteria.

The EO of Cupressus sempervirens L. presented antibacterial activity against Gram-positive and Gram-negative bacteria, showing the biggest inhibition with B. subtilis and E. coli. Additionally, the cypress essential oil was found to have moderate antimicrobial activity when compared to vancomycin (30 $\mathrm{mcg})$ and erythromycin $(15 \mathrm{mcg})$ as antibiotics [40].

The antibacterial activity could be affected by the solubility of the oil, the diffusion range in the agar and the evaporation $[41,42]$. In addition, the antibacterial activities of the essential oils suggest their usefulness in the treatment of various infectious diseases caused by the tested bacteria.

It is well known that Gram-negative bacteria are more resistant to essential oil compound antibacterial properties than Gram-positive bacteria because of hydrophobic lipopolysaccharide in the outer membrane which provides protection against different agents [43]; however, the obtained results indicated that the evaluated oil possesses selective antibacterial activity and its effect was pronounced against Gram-negative bacteria compared to Gram-positive ones.

\section{Conclusion}

According to our results, the essential oil of cypress cones is very rich in $\alpha$-pinene which is its major component. This compound is followed by $\Delta$-3-carene, $\alpha$-terpinyl acetate, $\beta$ caryophyllene, and cedrol. This composition is different from those found in other studies, and this difference may be due to climatic factors.

Furthermore, the evaluation of the antioxidant activity by chemical tests (total antioxidant capacity, DPPH, and ABTS) revealed a variable behavior of the essential oil against the used radicals. Moreover, $\mathrm{IC}_{50}$ values calculated are very low such that this reflects the high antioxidant power: they are of 176.45 and $151 \mu \mathrm{g} / \mathrm{mL}$ for ABTS and DPPH tests, respectively. The evaluation of the antibacterial activity of the tested essential oil showed that it possesses a significant activity. These promising results allow us to expand our studies to ascertain other activities of this essential oil such as antiparasitic, antifungal, and anticholinesterase activities.

\section{Conflict of Interests}

The authors declare that there is no conflict of interests regarding the publication of this paper.

\section{Acknowledgment}

This study was funded by the Tunisian Ministry of Higher Education and Scientific Research.

\section{References}

[1] I. Rawat, R. Ranjith Kumar, T. Mutanda, and F. Bux, "Dual role of microalgae: phycoremediation of domestic wastewater and biomass production for sustainable biofuels production," Applied Energy, vol. 88, no. 10, pp. 3411-3424, 2011.

[2] E. Zavarin, F. W. Cobb Jr., J. Bergot, and H. W. Barber, "Variation of the Pinus ponderosa needle oil with season and needle age," Phytochemistry, vol. 10, no. 12, pp. 3107-3114, 1971.

[3] C. Pierre-Leandri, X. Fernandez, L. Lizzani-Cuvelier et al., "Chemical composition of cypress essential oils: volatile constituents of leaf oils from seven cultivated Cupressus species," Journal of Essential Oil Research, vol. 15, no. 4, pp. 242-247, 2003.

[4] A. Cuenod, Flore analytique et synoptique de la Tunisie: Cryptogames vasculaires, Gymnospermes et monocotylédones, Imprimerie S.E.F.A.N, Tunis, Tunisia, 1954.

[5] V. R. Osório e Castro, "Chromium in a series of Portuguese plants used in the herbal treatment of diabetes," Biological Trace Element Research, vol. 62, no. 1-2, pp. 101-106, 1998.

[6] M. Assadi, "Cupressaceae," in Flora of Iran, M. Assadi, M. Khatamsaz, A. A. Maassoumi, and V. Mozaffarian, Eds., vol. 21, pp. 8-11, Research Institute of Forests and Rangelands, Tehran, Iran, 1998.

[7] N. Mascolo, G. Autore, F. Capasso, A. Menghini, and M. P. Fasulo, "Biological screening of Italian medicinal plants for antiinflammatory activity," Phytotherapy Research, vol. 1, no. 1, pp. 28-31, 1987.

[8] V. Darias, L. Bravo, R. Rabanal, C. S. Mateo, R. M. G. Luis, and A. M. H. Pérez, "New contribution to the ethnopharmacological study of the Canary islands," Journal of Ethnopharmacology, vol. 25, no. 1, pp. 77-92, 1989.

[9] W. Jochle, "Biology and biochemistry of reproduction and contraception," Angewandte Chemie, vol. 1, pp. 537-549, 1962.

[10] M. Ponce-Macotela, I. Navarro-Alegria, M. N. MartinezGordillo, and R. Alvarez-Chacon, "In vitro antigiardiasic activity of plant extracts," Revista de Investigacion Clinica, vol. 46, no. 5, pp. 343-347, 1994.

[11] A. Cáceres, L. M. Girón, S. R. Alvarado, and M. F. Torres, "Screening of antimicrobial activity of plants popularly used in guatemala for the treatment of dermatomucosal diseases," Journal of Ethnopharmacology, vol. 20, no. 3, pp. 223-237, 1987.

[12] N. J. Montvale, Anonymous. PDR for Herbal Medicines, Thomson PDR, 2004.

[13] K. M. M. Koriem, "Lead toxicity and the protective role of Cupressus sempervirens," Revista Latinoamericana de Química, vol. 37, no. 3, pp. 230-242, 2009.

[14] K. Mazari, N. Bendimerad, C. Bekhechi, and X. Fernandez, "Chemical composition and antimicrobial activity of essential oils isolated from Algerian Juniperus phoenicea L. and Cupressus sempervirens L.," Journal of Medicinal Plants Research, vol. 4, no. 10, pp. 959-964, 2010.

[15] J. Bellakhder, La Pharmacopée Marocaine Traditionnelle, Edition Ibis Press, Paris, France, 1997.

[16] J. Zhang, A. A. Rahman, S. Jain et al., "Antimicrobial and antiparasitic abietane diterpenoids from Cupressus sempervirens," Research and Reports in Medicinal Chemistry, vol. 2012, no. 2, pp. 1-6, 2012. 
[17] M. Boukhris, G. Regane, T. Yangui, S. Sayadi, and M. Bouaziz, "Chemical composition and biological potential of essential Oil from Tunisian Cupressus sempervirens L.," Journal of Arid Land Studies, vol. 22, no. 1, pp. 329-332, 2012.

[18] R. P. Adams, Identification of Essential Oil Components by Gas Chromatography/Mass Spectrometry, Allured Publishing, Carol Stream, Ill, USA, 1995.

[19] P. Prieto, M. Pineda, and M. Aguilar, "Spectrophotometric quantitation of antioxidant capacity through the formation of a phosphomolybdenum complex: specific application to the determination of vitamin E," Analytical Biochemistry, vol. 269, no. 2, pp. 337-341, 1999.

[20] C. I. G. Tuberoso, A. Kowalczyk, E. Sarritzu, and P. Cabras, "Determination of antioxidant compounds and antioxidant activity in commercial oil seeds for food use," Food Chemistry, vol. 103, no. 4, pp. 1494-1501, 2007.

[21] E. A. Hayouni, M. Abedrabba, M. Bouix, and M. Hamdi, "The effects of solvents and extraction method on the phenolic contents and biological activities in vitro of Tunisian Quercus coccifera L. and Juniperus phoenicea L. fruit extracts," Food Chemistry, vol. 105, no. 3, pp. 1126-1134, 2007.

[22] Y. M. Choi, D. O. Noh, S. Y. Cho, H. J. Suh, K. M. Kim, and J. M. Kim, "Antioxidant and antimicrobial activities of propolis from several regions of Korea," LWT-Food Science and Technology, vol. 39, no. 7, pp. 756-761, 2006.

[23] L. Riahi, H. Chograni, S. Ziadi, N. Zoghlami, and A. Mliki, "Essential oils of inus brutia and Cupressus sempervirens from Tunisia: chemical composition and antioxidant activity," Revue de la Société des Sciences Naturelles de Tunisie, vol. 38, pp. 55-60, 2012.

[24] A. L. Tapondjou, C. Adler, D. A. Fontem, H. Bouda, and C. Reichmuth, "Bioactivities of cymol and essential oils of Cupressus sempervirens and Eucalyptus saligna against Sitophilus zeamais Motschulsky and Tribolium confusum du Val," Journal of Stored Products Research, vol. 41, no. 1, pp. 91-102, 2005.

[25] G. Pauly, A. Yani, L. Piovetti, and C. Bernard-Dagan, "Volatile constituents of the leaves of Cupressus dupreziana and Cupressus sempervirens," Phytochemistry, vol. 22, no. 4, pp. 957-959, 1983.

[26] A. Loukis, E. Tsitsa-Tzardi, M. Kouladi, and M. Yuemei, "Composition of the essential oil of Cupressus sempervirens L. cones from Greece," Journal of Essential Oil Research, vol. 3, pp. 363$364,1991$.

[27] F. F. Kassem, F. M. Harraz, N. A. El-Sebakhy, H. L. De Pooter, and N. M. H. Schamp Abou-Schleib, "Composition of the essential oil of Egyptian Cupressus sempervirens L. cones," Flavour and Fragrance Journal, vol. 6, no. 3, pp. 205-207, 1991.

[28] I. Chéraif, H. Ben Jannet, M. Hammami, and Z. Mighri, "Contribution à l'étude de la composition chimique de l'huile essentielle des rameaux de Cupressus sempervirens L. poussant en Tunisie," Journal de la Société Chimique de Tunisie, vol. 7, pp. 75-82, 2005.

[29] S. A. Emami, M. H. Khayyat, M. Rahimizadeh, B. S. FazlyBazzaz, and J. Assili, "Chemical constituents of Cupressus sempervirens L. cv. cereiformis rehd. essential oils," Iranian Journal of Pharmaceutical Sciences, vol. 1, no. 1, pp. 39-42, 2004.

[30] M. Tognolini, E. Barocelli, V. Ballabeni et al., "Comparative screening of plant essential oils: phenylpropanoid moiety as basic core for antiplatelet activity," Life Sciences, vol. 78, no. 13, pp. 1419-1432, 2006.

[31] G. Sacchetti, S. Maietti, M. Muzzoli et al., "Comparative evaluation of 11 essential oils of different origin as functional antioxidants, antiradicals and antimicrobials in foods," Food Chemistry, vol. 91, no. 4, pp. 621-632, 2005.

[32] Ş. Baykan Erel, G. Reznicek, S. G. Şenol, N. Ü. Karabay Yavaşoğulu, S. Konyalioğlu, and A. U. Zeybek, "Antimicrobial and antioxidant properties of Artemisia L. species from western anatolia," Turkish Journal of Biology, vol. 36, no. 1, pp. 75-84, 2012.

[33] J. R. Soares, T. C. P. Dinis, A. P. Cunha, and L. M. Almeida, "Antioxidant activities of some extracts of Thymus zygis", Free Radical Research, vol. 26, no. 5, pp. 469-478, 1997.

[34] R. Mothana, R. Gruenert, P. J. Bednarski, and U. Lindequist, "Evaluation of the in vitro anticancer, antimicrobial and antioxidant activities of some Yemeni plants used in folk medicine," Pharmazie, vol. 64, no. 4, pp. 260-268, 2009.

[35] N. A. Ibrahim, H. R. El-Seedi, and M. M. D. Mohammed, "Constituents and biological activity of the chloroform extract and essential oil of Cupressus sempervirens," Chemistry of Natural Compounds, vol. 45, no. 3, pp. 309-313, 2009.

[36] S. A. Emami, J. Asili, Z. Mohagheghi, and M. K. Hassanzadeh, "Antioxidant activity of leaves and fruits of Iranian conifers," Evidence-Based Complementary and Alternative Medicine, vol. 4, no. 3, pp. 313-319, 2007.

[37] H. Ghazghazi, M. G. Miguel, B. Hasnaoui et al., "Phenols, essential oils and carotenoids of Rosa canina from Tunisia and their antioxidant activities," African Journal of Biotechnology, vol. 9, no. 18, pp. 2709-2716, 2010.

[38] Y. Lu and L. Y. Foo, "Antioxidant activities of polyphenols from sage (Salvia officinalis)," Food Chemistry, vol. 75, no. 2, pp. 197202, 2001.

[39] S. Singh, N. A. Anjum, N. A. Khan, and R. Nazar, "Metalbinding peptides and antioxidant defense system in plants: significance in cadmium tolerance," in Abiotic Stress and Plant Responses, N. A. Khan and S. Singh, Eds., pp. 159-189, IK International, New Delhi, India, 2008.

[40] S. Toroglu, "In vitro antimicrobial activity and antagonistic effect of essential oils from plant species," Journal of Environmental Biology, vol. 28, no. 3, pp. 551-559, 2007.

[41] J. Kim, M. R. Marshall, and C.-I. Wei, "Antibacterial activity of some essential oil components against five foodborne pathogens," Journal of Agricultural and Food Chemistry, vol. 43, no. 11, pp. 2839-2845, 1995.

[42] K. Cimanga, K. Kambu, L. Tona et al., "Correlation between chemical composition and antibacterial activity of essential oils of some aromatic medicinal plants growing in the Democratic Republic of Congo," Journal of Ethnopharmacology, vol. 79, no. 2, pp. 213-220, 2002.

[43] M. Vaara, "Agents that increase the permeability of the outer membrane," Microbiological Reviews, vol. 56, no. 3, pp. 395-411, 1992. 

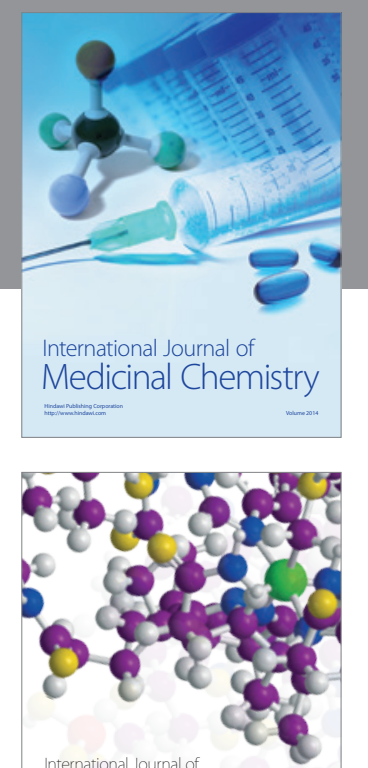

\section{Carbohydrate} Chemistry

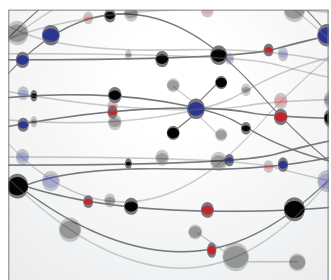

The Scientific World Journal
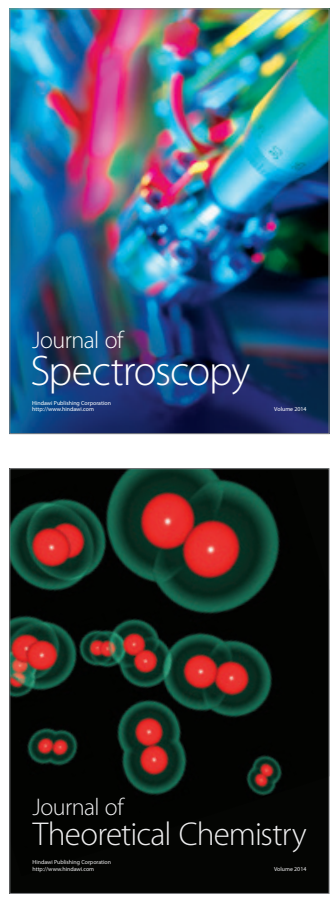
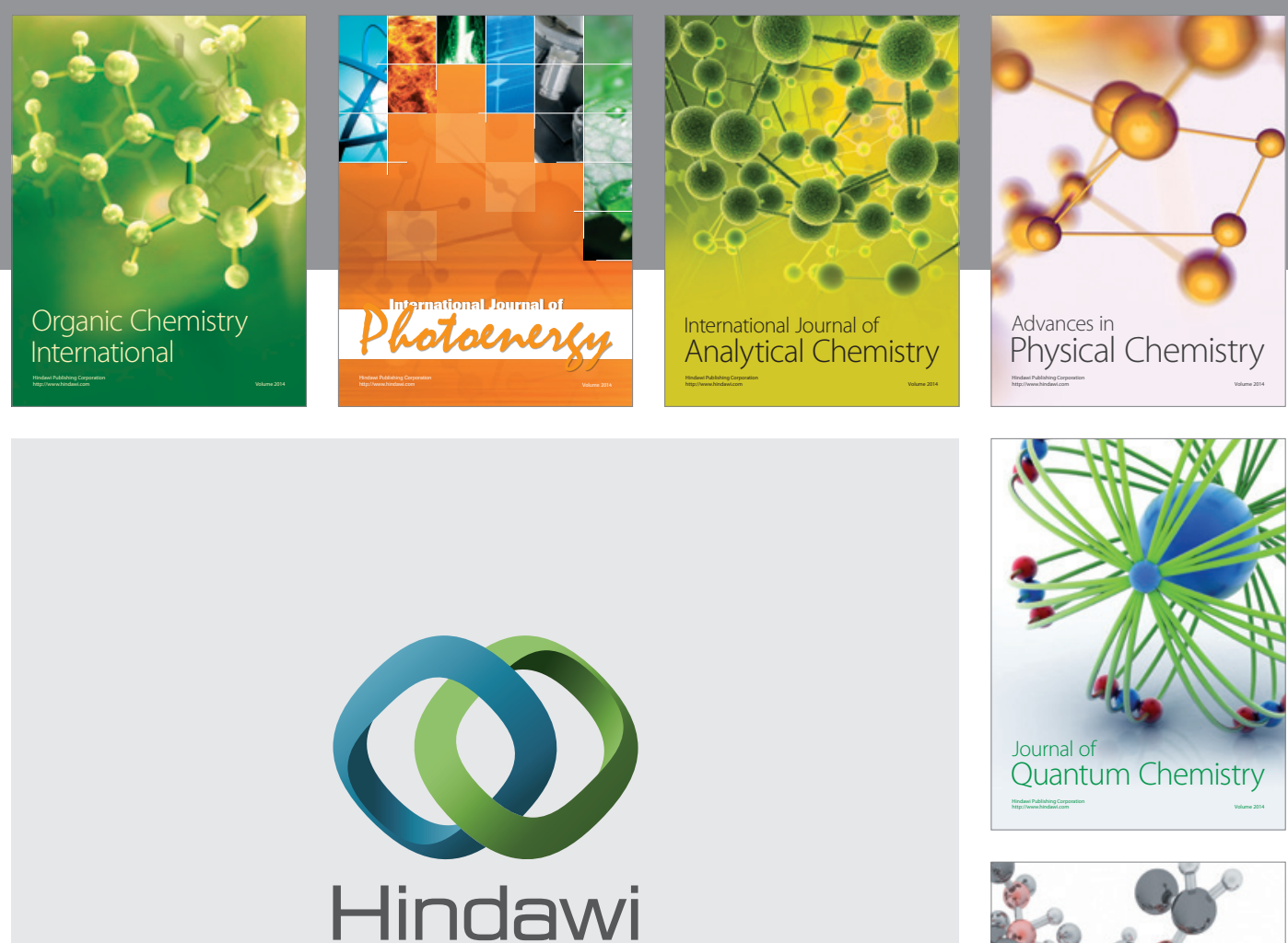

Submit your manuscripts at

http://www.hindawi.com

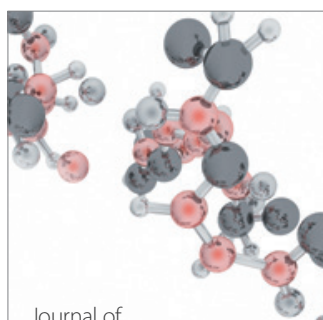

Analytical Methods

in Chemistry

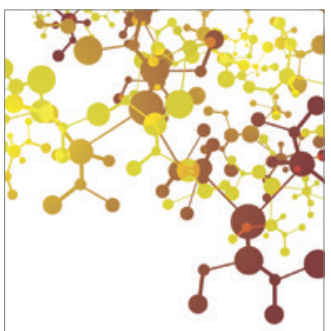

Journal of

Applied Chemistry

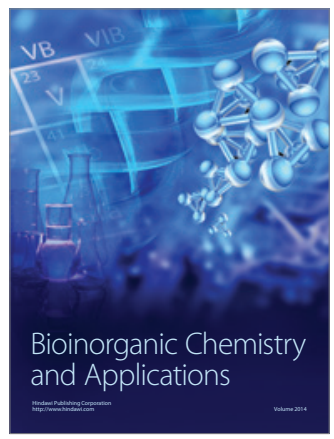

Inorganic Chemistry
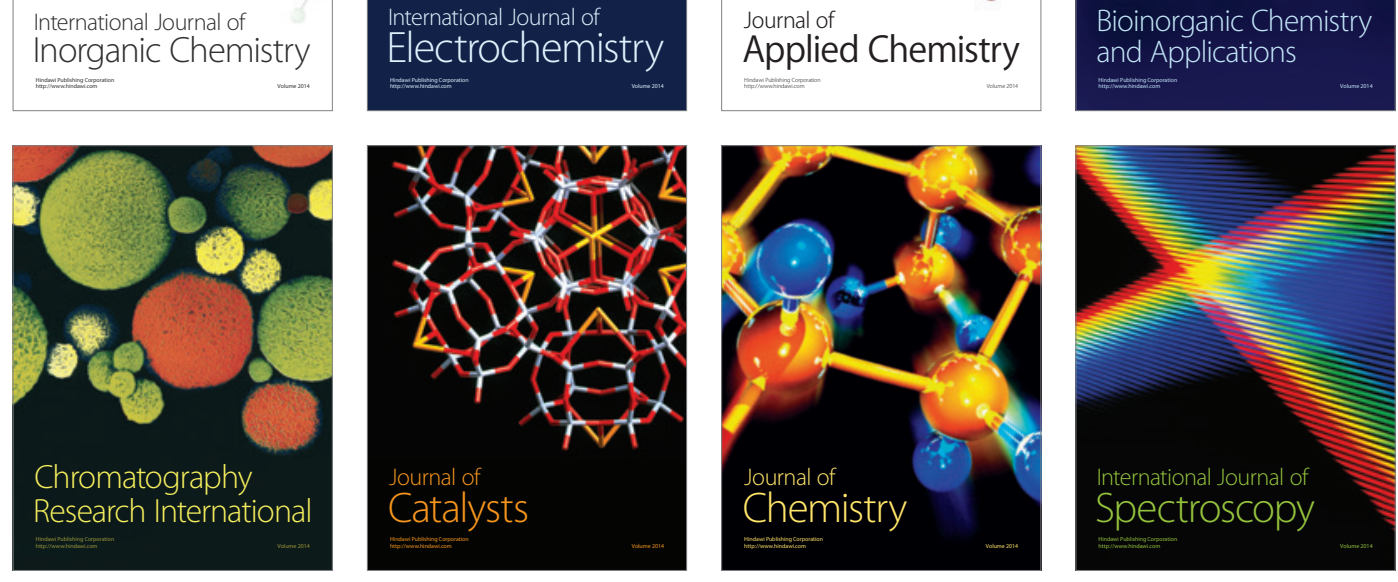